\title{
An Empirical Study of Trade Status and Determinants between China and "One Belt- One Road" Countries- Based on Trade gravity Model
}

\section{Qiannan Zhang}

Guangdong University of Finance \&amp; Economics

\section{XiaoNa He}

South China University of Technology

Miraj Ahmed Bhuiyan ( $\square$ ahmed.miraz@qq.com )

Guangdong University of Finance \&amp; Economics https://orcid.org/0000-0001-9321-972X

\section{Research Article}

Keywords: Trade Gravity Model, One Road- One Belt, Trade determinants, Trade Status

Posted Date: February 18th, 2021

DOI: https://doi.org/10.21203/rs.3.rs-192437/v1

License: (c) (i) This work is licensed under a Creative Commons Attribution 4.0 International License.

Read Full License 


\section{Abstract}

"One Road-One Belt", (Belt and Road Initiative, BRI) reminiscent of the Silk Road, is a massive infrastructure and trade project, initiated by China; that would stretch from East Asia to Europe, somehow recognized by the international community. Despite of criticism of this project, it is considered as an effective tool for promoting regional and bilateral trade deals. In this paper we have pointed out the problems that hindered the bilateral trades among countries along the route. Based on Trade gravity Model; bilateral trade model between China and the countries along the "Belt and Road" was empirically tested in the article, followed by some suggestions.

\section{Introduction}

\subsection{Research background and significance}

Today's world is experiencing unprecedented changes. At one hand, some developing countries represented by China have achieved unprecedented development, which promotes the globalization and continuous reform of the current economic governance system. On the other hand, some powerful countries like United States tried to deviate from the trend of economic globalization and advocated trade protectionism, which may hinder or even destroyed the stability of the current international order. "One Belt- One Road" initiative, in September 2013, conveying the strong desire and determination of China to build a better world with all other countries. "One Belt- One Road" is recognized by the international community. Over the years, the initiative has been implemented in action. More and more countries are willing to actively implement the "one belt and one road" initiative in all aspects of cooperation.

"One belt- One road" is an effective way to promote bilateral trade. This initiative has achieved good results in various fields over the past six years. In terms of trade connectivity, first, the level of trade and investment facilitation has been further improved. China has set up 12 pilot free trade zones open to the world, and the average tariff has been greatly reduced. Two, trade between China's and other countries along the border has been increasing in size. At present, China has established bilateral e-cooperation mechanisms with many countries along the belt and road. "One Belt- One Road" initiative will increase the economic and trade contacts between participating countries by $4.1 \%$, so the cooperation of "The belt and road" is a booster for expanding bilateral trade flows and achieving trade linkage among countries. It is also a powerful platform for countries to deepen exchanges and cooperation, participate in and actively promote economic globalization.

China's "One Belt- One Road" initiative is closely related to trade. It is of great significance to study the trade status and its influencing factors between China and the participating countries. Since the trade situation of China along the belt and road has been analyzed, the factors affecting bilateral trade can be broadened. China's "One Belt- One Road", trade scale, trade liberalization, better implementation of China's opening up strategy and China's opening up policy will also be of some reference value.

\subsection{Main contents and research methods}


The main content of this paper is divided into four parts

First part describes the development status of China and the countries along the "Belt and Road", the growth of trade and the main problems in the countries along the "Belt and Road" from 2008 to 2018, including Central Asia, South Asia, Central and Eastern Europe, West Asia and ASEAN countries. understanding the development status of economic and trade cooperation between China and countries along the "Belt and Road" and the impact of the "Belt and Road" initiative on bilateral trade cooperation also explains in this part.

A bilateral trade model between China and countries along the "Belt and Road" is constructed in the second part. Based on the trade gravity model, the independent variables and dependent variables of the bilateral trade model were set. The independent variables were the bilateral trade volume. The dependent variables included 3 basic variables and 3 dummy variables.

The bilateral trade model between China and the countries along the "Belt and Road" was tested empirically in the Third part. The overall empirical analysis of the bilateral trade model and the robustness test by region were performed using Eviews9.0, and the regression results were specifically explained as well.

The fourth part puts forward some suggestions to promote the expansion of trade scale. Based on the conclusions drawn from the regression results of the bilateral trade model, combined with the trade development situation of the countries along the "Belt and Road", relevant suggestions are made to promote China and the countries along the "Belt and Road". we put forward four targeted suggestions to promote trade between China and the "one belt and one road" countries.

\section{(ii) Research methods}

This paper mainly adopts four research methods. The details are as follows:

The first is the method of combining normative research and empirical research. The article collects and organizes a large number of domestic and foreign documents related to the trade influencing factors of countries along the "Belt and Road". Through the comprehensive classification and comparison of the similarities and differences between the literatures, we can understand the current research situation of the topic selection and lay the foundation for further determining its research contents. Based on the analysis of previous studies, this paper puts forward two hypotheses, and constructs a trade gravity model to empirically analyze the correctness of the assumptions, so as to increase the persuasiveness of the topic selection.

The second is a combination of qualitative analysis and quantitative analysis. The article qualitatively analyzes the trade development of the countries along the "Belt and Road" and quantitatively explains the development trend of the trade volume of the relevant countries through relevant data. The 
measurement part adopts the trade gravity model and performs regression analysis on the constructed model based on random effects. The results of the empirical analysis are explained in detail to further deepen the empirical conclusions of the article.

\subsection{Literature review}

(i) Foreign research on factors affecting trade in "One Belt- One Road"

As the "Belt and Road" has become an international public product benefiting hundreds of millions of people worldwide, all countries are generally concerned about the stimulating effect of the implementation of the "Belt and Road" initiative on their own economies, so there are not a few foreign studies on the economic and trade issues of the "Belt and Road". Fardella and Prodi (2017) analyzed the impact of the "Belt and Road" initiative on bilateral trade in Europe, and found that the development of new railway connections will benefit most of the Nordic and Central European countries [1]. Irshad (2018) estimated the bilateral trade potential between Pakistan and China. Research shows that the bilateral trade volume between the two countries is positively affected by GDP, religion, WTO, the opening of trade between the two countries and the common border, while being negatively affected by geographic distance and inflation. [2]. Shakur (2018) investigated the trade costs associated with China-EU agricultural trade from 2001 to 2015, and the results showed that the implementation of the "Belt and Road" initiative will reduce high trade costs, thereby significantly increasing China-EU bilateral agricultural trade [3]. The research of Siobhan and Nadia (2019) found that the construction and improvement of transportation facilities under the "Belt and Road" initiative will greatly reduce trade costs, thereby helping economies along the "Belt and Road" increase trade volume [4]. Ramasamy and Yeung (2019) compared the impact of the two "Belt and Road" initiatives (improving infrastructure and improving border management) on the trade of countries that signed the project, especially the countries along the six economic corridors. Improvements in management have the greatest impact on the exports of transit countries [5].

In the academic research on trade influencing factors, empirical analysis mainly uses the measurement method of trade gravity model. Papalia and Bertarelli (2015) used the gravity model of structural heterogeneity to study the heterogeneous effect of trade flows in trade integration regions (such as APEC and EU) [6]. Kazar (2018) found that bilateral trade increases with the similarity of domestic market size and country size [7]. Hussain, Wasim \& Nadeem (2019) use factor analysis and gravity model to estimate the impact of hard infrastructure such as transportation and telecommunications on bilateral export trade [8]. In addition, there are also a few literatures using the general equilibrium model to study the influence factors of trade. Alen (2019) "One Belt- One Road", and the other two countries, using the general equilibrium model, analyzes the impact of infrastructure construction and Optimization on trade in the context of "one belt and one road" [9].

(ii) Domestic research on factors affecting trade in "One Belt- One Road" 
The "Belt and Road" initiative has received close attention from the international community as soon as it was put forward, and related issues have also become a hot topic in China's domestic academic areas. Tan Xiujie and Zhou Maorong (2015) use the trade inefficiency model to study the impact of the four major factors of free trade agreements, trade facilitation, maritime infrastructure, and the openness of the financial industry on the trade of the southern countries of the "Belt and Road" [10]. Li Xiaohui (2016) analyzed the commodity trade structure between China and countries along the route and focused on the positive effect of the establishment of free trade zones on the growth of trade scale [11]. Liu Hongduo, Li Wenyu, Chen $\mathrm{He}$ (2016) analyzed the effect of cultural similarity and integration between China and countries along the "Belt and Road" on bilateral trade [12]. Zhang Huiqing (2017) concluded from the empirical analysis of the gravity model of export and import trade that economic scale, geographical distance and language similarity are the three main factors that determine the volume of import and export trade. In addition, signing FTAs and improving government supervision efficiency and quality can also Strengthen bilateral trade ties [13]. In the empirical analysis, Yang Qing and Zhang Cuizhen (2018) not only take economic scale and geographical distance as explanatory variables, but also focus on the positive impact of diplomatic relations on trade relations, and this factor also has lag effect [14]. Fang Ying and Ma Rui (2018) analyzed the factors affecting cultural trade of countries along the "Belt and Road". Besides, the influence of core variables (economic scale, geographical distance and common border), the study also showed that the improvement of tariff level and the extension of customs clearance would impede cultural trade between the two sides [15]. Deng Zixuan (2019) empirically found that in addition to economic scale and population size, economic system distance, common language, and free trade agreements can also increase bilateral cultural trade [16]. The empirical analysis of the influencing factors of the "Belt and Road" trade mainly includes measurement methods such as trade gravity model, structural vector autoregressive model and trade inefficiency model. Zuo Ximei (2016) empirically analyzed the trade influencing factors of 11 countries along the route based on the trade gravity model and found that there are differences in the trade potential of each region ${ }^{[17]}$. Zhang Jianguang and Zhang Peng (2017) identified in the analysis framework of the APR model that economic scale, cultural similarity, and WTO accession have a significant positive effect on the trade efficiency of the "Belt and Road" countries [18]. Cao Wei and Lin Shouwu (2017) found that the volatility of the RMB exchange rate is directly proportional to the bilateral trade volume by constructing an SVAR model [19]. Hou Wenyu (2018) uses a complex network model and a trade gravity model to analyze the trade patterns of countries along the route and the influencing factors of trade flows [20]. Zhang Yanyan and Yu Jinping (2018) combined the idea of adjacency effect and used the export trade model to study the impact of transportation infrastructure on the bilateral trade of countries along the "Belt and Road" [21]. Wan Yongbin (2019) studied the influence of economic volume, trade dependence, WTO accession and APEC on the bilateral trade flow between China and countries along the "Belt and Road" based on the expanded trade gravity model [22]. Li Xiaozhong and Du Tianhao (2019) use the stochastic frontier gravity model to study the influencing factors of trade flows, and use the trade inefficiency model to study the trade potential of 33 countries along the route. Empirical evidence shows that an open financial environment will also promote export trade [23]. 
(iii) Summary

In the process of sorting out the relevant literature at home and abroad, we can find that the existing literature has comprehensively considered the influencing factors of bilateral trade cooperation between China and countries along the belt and road, which has laid the foundation for theoretical demonstration and innovation in economy, trade, investment and other aspects. However, the sample countries selected in the current research are relatively limited, mainly concentrated in certain countries or a few regions, and the same factor has different degrees of influence on different regions of the countries along the "Belt and Road". There are few papers on this in-depth study. Based on the analysis and reference of previous studies, the article puts forward two hypotheses: First, economies of scale, quality of port infrastructure, signing of free trade agreements and accession to APEC will have a positive effect on bilateral trade, while geographic distance will have a negative effect on bilateral trade, while geographical distance will have a negative effect. Second, the degree of influence of the same factor on countries in different regions along the route is heterogeneous. To this end, the article will collect and sort out the import and export trade volume data between China and 45 countries along the "Belt and Road" during the 11 years from 2008 to 2018. First, establish a trade gravity model and perform regression analysis on the entire model based on random effects. The countries are divided into five groups according to their geographical locations, and the regional robustness tests are conducted to empirically study the main factors affecting the growth of bilateral trade between China and the countries along the "Belt and Road", and analyze the differential impact of these factors on different regions. Further put forward powerful measures to promote the growth of bilateral trade between China and countries along the "Belt and Road" and promote the sustainable development of the "Belt and Road" initiative.

\section{Current Status Of Trade Development Between China And Countries Along The "belt And Road"}

The "Belt and Road" initiative has stimulated the economic development of countries along the route from all aspects, greatly improved the quality of life of local people, and enabled more citizens to enjoy various benefits. This part mainly focuses on the perspective of trade connectivity, analyzes the trade growth of countries along the "Belt and Road" from 2008 to 2018, and understands the impact of the "Belt and Road" initiative on bilateral trade cooperation between China and countries along the route. In order to cover as many cooperation areas as possible, the article uses a total of 45 countries in the five regions along the route as sample countries, including 5 Central Asia, 6 South Asia, 14 Central and Eastern Europe, 10 ASEAN, and 10 West Asia.

\subsection{Current situation of trade development between China and five Central Asian countries}

China has a long history of exchanges with Central Asia. As early as the Han Dynasty, China began a journey of foreign exchanges with Central Asia. Today, the "Belt and Road" initiative has helped the two sides continue to expand their cooperation in all aspects. In terms of economic and trade cooperation, the opening of the China-Kazakhstan agricultural green channel has facilitated the "going out" strategy of 
agricultural products in the rich Xinjiang region, and the smooth operation of international freight trains has promoted Ningxia's opening up toward west. In terms of economic volume, the gross domestic product of the five Central Asian countries showed a fluctuating growth trend from 2008 to 2018, and the scale of trade continued to expand. Kazakhstan's GDP ranks first among the five countries. Uzbekistan and Turkmenistan have seen their GDP rise during the last 11 years. As Uzbekistan is rich in cherries and mung beans, its exports of fruits and vegetables to China have also increased. In 2018, China became Uzbekistan's fifth largest fruit and vegetable export market.

From the perspective of bilateral trade volume, the growth of bilateral trade between China and the five Central Asian countries has different characteristics. First of all, China and Kazakhstan have maintained close cooperation for a long time, but the bilateral trade volume has dropped significantly since 2013. The main reason may be that Kazakhstan mainly exports mineral products to China, and the commodity structure is relatively single. In addition, the decline of international raw material prices is another major adverse factor. Secondly, among the five Central Asian countries, the bilateral trade between Turkmenistan and China is not large, but it is the country with the fastest growth rate of bilateral trade. As can be seen from Figure 1, compared with 2008, the bilateral trade volume between China and Turkmenistan increased more than 10 times in 2018, which is mainly due to Turkmenistan's rich natural resources, especially the rapid growth of natural gas exports. After long-term close cooperation and development, the scale of bilateral trade between China and Turkey has been greatly increased in the past 20 years.

\subsection{Trade development between China and South Asia}

China and South Asia are geographically adjacent, with similar cultures and customs, and have a solid foundation for cooperation. There are three economic corridors in South Asia, and the important position of the China-Pakistan Economic Corridor is self-evident. On the one hand, a large number of basic engineering projects in the "Belt and Road" plan have been implemented, such as Hambantota Port in Sri Lanka, Payara Coal-fired Power Station in Bangladesh, China-Malaysia Friendship Bridge in Maldives, and Shangma Xiangdi in Nepal A hydropower station. On the other hand, under the promotion of convenient infrastructure, China and South Asian countries have increasingly deepened their economic and trade cooperation. In terms of total trade volume, the scale of trade between China and the six countries in South Asia is expanding year by year.

As shown in Figure 2, the trade scale of India, Pakistan, and Bangladesh occupies a dominant position among the six countries in South Asia. At present, the bilateral transaction volume between China and the remaining five countries, including Afghanistan and Sri Lanka, is relatively small. However, as the One Belt-One Road initiative progresses, China and the six South Asian countries will develop more and more extensive economic and trade cooperation. First of all, among the six South Asian countries, the bilateral trade volume between China and India has shown an increasing trend year by year. As of 2018, the bilateral import and export trade volume between China and India has increased to US\$95.731 billion, far exceeding the rest of the countries. The great development of China-India cooperation has benefited from 
many factors, including the profound cultural foundation, the convenience of geographical location, and the similarity of population characteristics. In addition, China's strong infrastructure construction capabilities also cater to India's urgent needs, and India's developed software and Internet service industries also complement China's advantages. Secondly, since the beginning of 2017, the bilateral trade volume between China and Pakistan has increased significantly. This is mainly due to the leading role of the China-Pakistan Economic Corridor. Many projects under its framework have not only effectively solve the two major problems of power shortage and backward transportation infrastructure faced by Pakistan, but also create a lot of benefits for Pakistan every year. Thirdly, the bilateral trade volume between China and Bangladesh has been increasing year by year, especially in terms of contracting projects, and ChinaBangladesh economic and trade cooperation has entered a new stage.

\subsection{Current situation of trade development between China and Central \& Eastern European countries}

Since the beginning of 2012, China has maintained close cooperative relations with Central and Eastern European countries. Now the "16+1" cooperation mechanism has lasted for 7 years. In April 2019, Greece's accession made the "16+1" model officially expanded into the "17+1" cooperation framework. This means that the "one belt" initiative has been recognized more and more in the central and Eastern Europe, and the cooperation between China and the central and Eastern European countries has great potential for development.

As shown in Figure 3, the total trade volume of Poland, Czech Republic and Hungary accounts for $63 \%$ of the total trade volume between China and Central \& Eastern. Among them, Poland is known as the jewel of the "Belt and Road". Compared with other Central and Eastern European countries, Poland occupies a great advantage in terms of geographical location, population, land area and economic aggregate. Coupled with its stable economic situation and mature business environment, these factors will undoubtedly boost the long-term development of pragmatic cooperation. In addition, the total volume of bilateral trade between China and other central and Eastern European countries is not large, but it also shows a trend of gradual growth. In particular, Slovenia has a very significant growth rate, and there are broad prospects for economic and trade cooperation with China.

\subsection{The current situation of trade development between China and ASEAN countries}

Over the past six years, the "Belt and Road" initiative has won great praise from local leaders in the ASEAN region, and the cooperation and development between ASEAN countries and China in all aspects is in a good development trend. The Belt and Road Initiative has achieved many fruitful results in Southeast Asia. Construction of the China-Laos railway has begun, the China-India-Yawan high-speed railway has been fully completed, and the China-Vietnam Yongxin project will soon be put into operation. Over the years, China has continued to maintain its position as the largest trading partner of ASEAN.

As shown in Figure 4, the bilateral trade volume between Singapore, Malaysia, Indonesia, Thailand, Vietnam and the Philippines is developing rapidly, while the remaining four countries have seen relatively small increases. First of all, the rapid development of Vietnam is the most eye-catching. The trade 
structure between China and Vietnam is becoming more and more reasonable. The areas of bilateral trade cooperation are no longer limited to low-tech industries such as agricultural and sideline products, but are more capital-intensive and technology-intensive. It can be seen that the degree of economic and trade cooperation between the two countries is constantly deepening. Secondly, the development of the Philippines is also very gratifying. The bilateral trade volume between China and the Philippines has grown from 72 million US dollars in 1975 to 5.131 billion US dollars in 2017, making great progress. With the continuous deepening of China-ASEAN Free Trade Area cooperation and the gradual implementation of the "ASEAN Interconnection Master Plan 2025", China-Philippines cooperation has huge room for development. With the joint efforts of China and ASEAN countries, the two sides will continue to deepen bilateral trade cooperation on the convenient platform provided by the "Belt and Road" initiative.

\subsection{Current situation of trade development between China and countries in West Asia}

West Asia is well-known as "world oil treasure house". Its exports to China have always been dominated by energy and resources such as oil, natural gas, and mineral resources. However, the level of manufacturing industry in West Asia is low, and public infrastructure such as transportation, water \& electricity is very backward. Local residents often face problems such as insufficient power supply and inconvenient transportation. Today, China's "One Belt, One Road" initiative has brought good news to the improvement of the quality of public infrastructure in West Asia. At the same time, the rich oil and other energy and resources in West Asia also cater to the needs of China's modern industrial development. Therefore, the proposal of "one belt - one road" initiative is consistent with the interests of the two sides in economic and social development.

It can be seen from Figure 5 that the overall bilateral trade volume between China and ten countries in West Asia shows a fluctuating growth trend. In recent years, my country and Saudi Arabia have conducted frequent trade exchanges. As the mutual complementarity of energy and industrial cooperation between the two sides has gradually strengthened, the projects planned by the "Belt and Road" Initiative have been implemented to a greater extent in West Asia. There are still many influencing factors that are not conducive to economic and trade cooperation between the two sides. The most prominent problem is the political instability in West Asia and the turbulent situation in these countries, which brings great challenges to bilateral cooperation. In addition, issues such as religious conflicts, ethnic discrimination, and cultural estrangement also bring a crisis of trust to each other. It is inevitable that some differences will occur in cooperation, which hinders further exchanges and cooperation between the two sides. Despite the difficulties, under the "Belt and Road" initiative, China and countries in West Asia have worked hard to reach a consensus on cooperation and enhance mutual understanding of each other's cultures, thus laying a foundation for the continued positive development of bilateral economic and trade cooperation.

\section{Bilateral Trade Model Set And Data Selection}


According to the previous literature review, it is very suitable to use the trade gravity model to measure the influencing factors of bilateral trade volume. Therefore, this section will set the independent variables and dependent variables of the empirical analysis based on the trade gravity model. The dependent variable is the bilateral trade volume, and the independent variables include three basic variables and three dummy variables. In order to stabilize the data, the article adopts a logarithmic form for each variable into the model. The explanation of variables and the explanation of expected symbols are conducive to making full preparations for the next step of empirical analysis.

\subsection{Setting of bilateral trade model and selection of explanatory variables}

The trade gravity model is widely used in the academic research on trade flows. The traditional trade gravity model holds that the farther the distance between the two countries are, smaller the trade gravity is, the smaller the possibility of cooperation between the two sides; and larger the economic volume of the two countries, the greater the gravity of trade, the more likely the two countries will have trade cooperation. Therefore, early economists set the basic form of the trade gravity model as follows: please see formula 1 in the supplementary files.

In this model, $X$ represents the scale of trade between the two countries, $Y$ represents the GDP of the economy, and $\mathrm{D}$ represents the geographic distance between the two countries. Since then, dummy variables such as common language and common boundary were introduced into the model by scholars in the 1980s and 1990s. In addition, Lucian (2001), Wang Kailei (2007) and other Chinese and foreign scholars also use gravity model to analyze the system quality index variables, such as estimating the trade flow between members of the preferential trade agreement. The expanded trade gravity model can more comprehensively measure the impact of qualitative and quantitative factors such as politics, economy, and institutions on the scale of bilateral trade between the two countries. Therefore, this article draws on this idea and uses the bilateral trade volume between China and the countries along the "Belt and Road". TRA is the explained variable. The gross domestic product (GDPi and GDPj, respectively) of China and the countries along the "Belt and Road", the geographic distance between the two countries DIS and the quality of port infrastructure WEF are used as the explanatory variables, and three dummy variables are added, including common border (BOR), free trade agreement (FTA) and Shanghai Economic Cooperation Organization (APEC)

\subsection{Data source and variable description of bilateral trade model}

The article collects "One Belt- One Road", 45 countries' data in 2008-2018 years, and establishes the trade gravity model. This model takes China "One Belt- One Road" and the other side of the "I" country as the dependent variable. The data are from the world bank database, and the sum of imports and exports between China and the sample countries is compiled and summed up by adding $\mathrm{J}$ to the TRA. Based on the above-mentioned extended trade gravity model, this model selects seven independent variables,

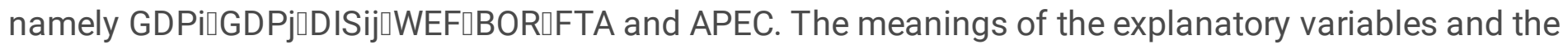
relevant data sources are shown in Table 1, which are described as follows: 
Table 1 meanings of explanatory variables and data sources

\begin{tabular}{|c|c|c|c|}
\hline $\begin{array}{l}\text { Explanatory } \\
\text { variables }\end{array}$ & Meaning & $\begin{array}{l}\text { Expected } \\
\text { symbol }\end{array}$ & Data Sources \\
\hline$G D P_{i}$ & $\begin{array}{l}\text { China's economic } \\
\text { volume, unit: } 100 \\
\text { million U.S. dollars }\end{array}$ & + & $\begin{array}{l}\text { World Bank Database } \\
\text { https://data.worldbank.org.cn/ }\end{array}$ \\
\hline$G D P_{j}$ & $\begin{array}{l}\text { The economic } \\
\text { volume of countries } \\
\text { along the "Belt and } \\
\text { Road", unit: US\$100 } \\
\text { million }\end{array}$ & + & $\begin{array}{l}\text { World Bank Database } \\
\text { https://data.worldbank.org.cn/ }\end{array}$ \\
\hline$D I S_{i j}$ & $\begin{array}{l}\text { Geographical } \\
\text { distance between } \\
\text { China and the } \\
\text { capitals of countries } \\
\text { along the route, in } \\
\text { kilometers }\end{array}$ & - & $\begin{array}{l}\text { CEPII database } \\
\text { http://www.cepii.fr/CEPII/en/bdd_modele/bdd.asp }\end{array}$ \\
\hline WEF & $\begin{array}{l}\text { The quality of port } \\
\text { infrastructure is } \\
\text { divided into } 1 \sim 7 \\
\text { grades }\end{array}$ & + & $\begin{array}{l}\text { World Bank Database } \\
\text { https://data.worldbank.org.cn/ }\end{array}$ \\
\hline$B O R$ & $\begin{array}{l}\text { Do China and the } \\
\text { "Belt and Road" } \\
\text { countries have a } \\
\text { common border }\end{array}$ & + & $\begin{array}{l}\text { CEPII database } \\
\text { http://www.cepii.fr/CEPII/en/bdd_modele/bdd.asp }\end{array}$ \\
\hline FTA & $\begin{array}{l}\text { Does China sign free } \\
\text { trade agreements } \\
\text { with trading } \\
\text { countries }\end{array}$ & + & $\begin{array}{l}\text { China Free Trade Zone Service Network } \\
\text { http://fta.mofcom.gov.cn/ }\end{array}$ \\
\hline$A P E C$ & $\begin{array}{l}\text { Are the countries } \\
\text { along the "Belt and } \\
\text { Road" a member of } \\
\text { APEC }\end{array}$ & + & APEC official website https://www.apec.org/ \\
\hline
\end{tabular}

GDPi and GDPj respectively represent the economic volume of China and country $j$ along the "Belt and Road". Measured by GDP, the size of a country's economic volume is closely related to its import and export capabilities. In the bilateral trade model, the GDP levels of the two countries can reflect the country's supply capacity and potential demand for related trade products, and its expected impact on the bilateral trade volume is positive.

DISij represents the geographical distance between China and the country of study. Most previous studies believe that the farther the geographical distance is, the higher the trade cost and information cost will be. With the development of trade cost theory, scholars further proposed that geographic distance will reduce the breadth and depth of trade, and even affect the trade price of products, thereby reducing the volume 
of trade between the two countries. Therefore, in the bilateral trade model, the expected sign of the explanatory variable DISij is negative.

WEF stands for the quality of port infrastructure. This indicator can be used to measure the construction of a country's marine transportation infrastructure. It can, not only indicate the port and logistics performance of the country, but also indirectly reflect the level of a country's trade facilitation. Therefore, the higher the quality of port infrastructure construction, the better the customs clearance procedures and the improvement of trade facilitation, thereby promoting trade between the two sides. The expected sign is positive. The World Bank database divides the index into $1 \sim 7$ levels. The closer to 1, the poorer the quality of port infrastructure, and the closer to 7 , the more efficient and better the quality of port infrastructure.

BOR represents whether China and the "Belt and Road" countries have a common border. Generally speaking, there will be a certain degree of similarity in cultural customs between countries that share a common border, with a higher degree of cultural integration and a closer geographical distance, which reduces trade costs and provides more opportunities for trade cooperation. Therefore, the expected sign of this variable is positive. At the same time, this variable is a dummy variable. If China and the research target country share a common border, i.e. border, the value is 1 , otherwise the value is 0 .

FTA and APEC represent whether China has signed free trade agreements with trading countries and whether it is a member of APEC. Free trade agreements are agreements signed between two or more countries aimed at promoting the circulation of production factors such as commodities, services, human resources and capital, eliminating trade barriers and promoting economic development. Signing a free trade agreement can bring preferential tariff policies to the signatories. At the same time, it can simplify customs procedures, optimize customs clearance procedures, and improve customs clearance efficiency. These factors are conducive to reducing customs clearance costs and trade costs, promoting trade facilitation, and increasing bilateral trade. APEC is also an institutional arrangement aimed at promoting world economic growth and promoting the multilateral free trade system through investment facilitation and trade facilitation. Therefore, the expected signs of FTA and APEC in the model are both positive, and these two variables are also dummy variables. If China has signed a free trade agreement with a trading country or the trading country is an APEC member, the value is 1 , otherwise the value is 0 .

\section{The Empirical Process Of Bilateral Trade Model Between China And Countries Along The "belt And Road"}

This part uses Eviews 9.0 to conduct an empirical analysis of the bilateral trade model. Before the overall regression, the article first conducts unit root test and cointegration test on the relevant panel data of 45 countries along the "Belt and Road" to avoid data non-stationary and pseudo-regression. After passing Hausman's test, the article uses random effects to perform regression analysis on the overall bilateral trade model. In order to further illustrate the degree of influence of various factors on trading countries in 
different regions, the article will divide the 45 countries along the route into 5 groups of Central Asia, South Asia, Central and Eastern Europe, ASEAN and West Asia for robustness testing.

4.1 The Empirical process of the overall bilateral trade model

As the article selected relevant data from 2008 to 2018, involving three dimensions of time, country and variables, it is suitable to use a static panel model for analysis. Pseudo-regression is prone to appear in the panel model, so the article chooses four methods of unit root test to measure the stability of the data to avoid this problem. It can be seen from Table 2 that the original sequence of "LNWEF" is stationary data, while the original series of "LNTRA?", "LNGDPi?" and "LNGDPj?" are non-stationary data, indicating that there is a unit root, and it is necessary to make a difference for the relevant variables and continue to test them.

Table 2 Unit root test of each explanatory variable

\begin{tabular}{|lllll|}
\hline & ADF-FisherTest & LLCTest & IPSTest & PP-FisherTest \\
\hline \multirow{2}{*}{ LNTRA } & 191.907 & -19.09 & -4.46 & 91.444 \\
& $(0.00)$ & $(0.00)$ & $(0.00)$ & $(0.4377)$ \\
\hline \multirow{2}{*}{ NNGDP $_{i}$} & 163.938 & -20.10 & -3.01 & 9.680 \\
& $(0.00)$ & $(0.00)$ & $(0.00)$ & $(1.00)$ \\
\hline \multirow{2}{*}{ NNGDP $_{j}$} & 140.698 & -7.56 & -1.96 & 116.539 \\
& $(0.0005)$ & $(0.00)$ & $(0.026)$ & $(0.0314)$ \\
\multirow{2}{*}{ LNWEF } & 165.131 & -19.35 & -4.24 & 218.508 \\
& $(0.00)$ & $(0.00)$ & $(0.00)$ & $(0.00)$ \\
\hline
\end{tabular}

Note: the data in brackets are the concomitant probability of the statistics, and the data above the brackets are t statistics.

The first-order difference series of "LNTRA?" is stationary, while the first-order difference series of "LNGDPi?" and "LNGDPj?" are still non-stationary data. Therefore, these two variables need to be further tested for the second-order difference series. The results in Table 3 show that the quadratic difference sequence of "LNGDPi?" and "LNGDPj?" is stable.

Table 3: Unit root test for non-stationary explanatory variables 


\begin{tabular}{|lllll|}
\hline & ADF-FisherTest & LLCTest & IPSTest & PP-FisherTest \\
\hline DLNTRA & 191.907 & -19.09 & -4.46 & -4.021 \\
& $(0.00)$ & $(0.00)$ & $(0.00)$ & $(0.00)$ \\
\hline DLNGDP $i$ & 163.938 & -20.10 & -3.01 & 68.312 \\
& $(0.00)$ & $(0.00)$ & $(0.00)$ & $(0.957)$ \\
DDLNGDP $i$ & 163.938 & -20.10 & -3.01 & 183.234 \\
& $(0.00)$ & $(0.00)$ & $(0.00)$ & $(0.00)$ \\
\hline DLNGDP & 162.667 & -7.56 & -2.541 & 259.867 \\
& $(0.00)$ & $(0.00)$ & $(0.055)$ & $(0.00)$ \\
\hline DDLNGDP & 162.667 & -7.56 & -4.360 & 259.867 \\
& $(0.00)$ & $(0.00)$ & $(0.00)$ & $(0.00)$ \\
\hline
\end{tabular}

Note: $\Delta$ is the first-order difference sequence, and $\Delta$ is the second-order difference sequence. The data in brackets is the concomitant probability of the statistic, and the data above the bracket is the t statistic.

From the above analysis, we can see that there is a unit root for the "LNTRA?" sequence, and two-unit roots for the "LNGDPi?" and "LNGDPj?" sequences, that is, the variable data of the bilateral trade model is not stationary. According to the above analysis, regression analysis cannot be carried out directly at this time. For this non-stationary panel variable, the authors chose the ADF cointegration test. The results are shown in Table 4. Whether it is the ADF cointegration test within or between dimensions, the corresponding $p$ values are all rejected at the $1 \%$ significance level of the null hypothesis, which indicates that there is a co-integration relationship between the panel data of the bilateral trade model at this time, and the phenomenon of pseudo regression can be avoided when performing regression analysis.

Table 4: ADF cointegration test

\begin{tabular}{|c|c|c|c|c|}
\hline $\begin{array}{l}\text { Explained } \\
\text { variable }\end{array}$ & explanatory variable & & $\begin{array}{l}\mathrm{t} \\
\text { statistics }\end{array}$ & $\begin{array}{l}\text { probability value } \\
\text { p }\end{array}$ \\
\hline \multirow[t]{2}{*}{ LNTRA } & $\angle N G D P_{j} \nabla L N G D P_{j} \nabla L N W E F$ & $\begin{array}{l}\text { In-group } \\
\text { statistics }\end{array}$ & -4.222998 & 0.0000 \\
\hline & & $\begin{array}{l}\text { In-group } \\
\text { statistics }\end{array}$ & -6.419179 & 0.0000 \\
\hline
\end{tabular}

The article uses the statistical test method of the Hausman test to determine the appropriate measurement method for the bilateral trade model. According to the principle of the test, if the $p$ value of the test result is far more than 0.05 , the null hypothesis is accepted and choose random effect, otherwise 
the fixed effect is selected. The test results are shown in Table 5. The p value of the Hausman test result is 0.1221 , indicating that the bilateral trade model uses random effects to measure the effect better.

Table 5: Hausman test

\begin{tabular}{|llll|}
\hline Testing method & Chi-Sq.Statistic & Chi-Sq.d.f. & Prob \\
\hline Random cross section & 7.273261 & 4 & 0.1221 \\
\hline
\end{tabular}

After dealing with the non-stationarity of the panel data and determining the random effects of the model, this paper uses Eviews 9.0 to conduct a multiple regression analysis on the bilateral trade model, and obtains the degree of influence of each variable on the bilateral trade volume from 2008 to 2018 .In order to strengthen the explanation of GDP, geographical distance, port infrastructure quality and other influencing factors, this paper adopts the method of gradually introducing regression variables. The empirical results are shown in Table 6 model (1) (5).

We can see from Table 6 that the modified R2 of model (5) is 0.58 , the F statistic is 97.24 , and the p value is 0.00 . It can be seen that the overall goodness of fit of the bilateral trade model is relatively good, and it is significant at the level of $1 \%$. The significance level of LNGDPi and LNGDPj in each model exceeds $1 \%$. The regression coefficients of LNGDPi and LNGDPj were 0.571, 0.567, 0.561, 0.542, 0.542 and 0.724, $0.707,0.718,0.766,0.764$, respectively. On the whole, for every $1 \%$ increase in GDPi, the bilateral trade volume will increase by approximately $0.54 \%$, and for every $1 \%$ increase in GDPj, the bilateral trade volume will increase by approximately $0.76 \%$. Therefore, the economic scale of China and the countries along the "Belt and Road" can significantly promote bilateral trade. The growth of GDP, and the driving force of the GDP of trading countries is greater. The sign of the LNDIS regression coefficient is sometimes positive and sometimes negative, but from the perspective of model (5), the regression coefficient is -1.115 and the p-value is 0.06 , indicating that for every $1 \%$ increase in geographic distance, the bilateral trade volume decreases by approximately $1.115 \%$, and Significant at the $10 \%$ level, which is consistent with the expectations. The regression coefficients of LNWEF are all positive. On the whole, for every $1 \%$ increase in the port infrastructure quality index, the bilateral trade volume will increase by approximately $0.33 \%$, which is significant at the $5 \%$ level.

The three dummy variables BOR, FTA and APEC can all have a positive effect on the increase of bilateral trade volume, and FTA has a higher degree of influence. From the perspective of model (5), for every $1 \%$ increase in BOR, the bilateral trade volume will increase by approximately $0.23 \%$; for every $1 \%$ increase in FTA, the bilateral trade volume will increase by approximately $1.67 \%$, which is significant at the level of $1 \%$; for every $1 \%$ increase in APEC, The bilateral trade volume increased by approximately $0.04 \%$.

Table 6:Regression results of bilateral trade model 


\begin{tabular}{|c|c|c|c|c|c|}
\hline & (1) & (2) & (3) & (4) & (5) \\
\hline \multirow[t]{2}{*}{$\angle N G D P_{i}$} & $0.570869 * * *$ & $0.566665^{\star \star \star}$ & $0.561290 * \star \star *$ & $0.541612^{\star \star \star \star}$ & $0.542468 * * *$ \\
\hline & (12.95008) & (12.86719) & (12.73171) & (12.50870) & (12.46479) \\
\hline \multirow[t]{2}{*}{$\angle N G D P_{j}$} & $0.723938^{\star \star \star \star}$ & $0.706809 * \star \star$ & $0.718168^{\star \star *}$ & $0.766241^{\star \star \star}$ & $0.763891^{\star \star *}$ \\
\hline & $(0.060473)$ & (11.51611) & (11.70002) & (13.46972) & (13.15731) \\
\hline \multirow[t]{2}{*}{ LNDIS } & 0.088173 & 0.007831 & 0.555110 & $-1.126008^{\star \star}$ & $-1.114786^{*}$ \\
\hline & $(0.216167)$ & $(0.019096)$ & $(1.065979)$ & $(-1.972980)$ & $(-1.884687)$ \\
\hline \multirow[t]{2}{*}{ LNWEF } & & 0.246261 & $0.275402^{\star}$ & $0.326361^{\star *}$ & $0.326372^{\star \star}$ \\
\hline & & $(1.489121)$ & (1.657242) & (2.004394) & $(2.000689)$ \\
\hline \multirow[t]{2}{*}{$B O R$} & & & $0.736166^{\star}$ & 0.219180 & 0.231719 \\
\hline & & & (1.668727) & $(0.574093)$ & $(0.554164)$ \\
\hline \multirow[t]{2}{*}{ FTA } & & & & 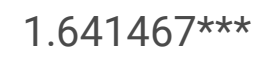 & $1.665468^{\star \star \star *}$ \\
\hline & & & & $(4.475906)$ & (3.478030) \\
\hline \multirow[t]{2}{*}{$A P E C$} & & & & & 0.044916 \\
\hline & & & & & (0.082993) \\
\hline \multirow[t]{2}{*}{ C } & $-8.607024^{\star \star}$ & $-8.079963^{\star \star}$ & $-12.97248^{\star \star \star}$ & 1.745031 & 1.651219 \\
\hline & $(-2.448278)$ & $(-2.294449)$ & $(-2.853963)$ & $(0.348955)$ & $(0.318757)$ \\
\hline $\cos R^{2}$ & 0.555450 & 0.556544 & 0.558287 & 0.578381 & 0.576933 \\
\hline $\mathrm{F}$ स्वा & 206.7452 & 155.9942 & 125.8748 & 113.9455 & 97.23748 \\
\hline $\mathrm{PL}$ & 0.000000 & 0.000000 & 0.000000 & 0.000000 & 0.000000 \\
\hline
\end{tabular}

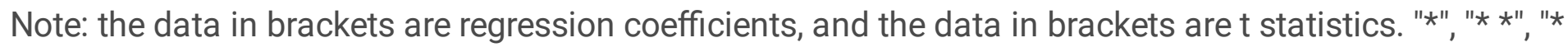
*", "* *" were significant at $10 \%, 5 \%$ and $1 \%$ levels, respectively.

- The robustness test of regional bilateral trade model

There are many countries along the "Belt and Road". In order to further illustrate the impact of economic scale, geographical distance and other factors on China's bilateral trade volume with various regions, the article will study the group of countries and conduct robustness tests on panel data in Central Asia, South Asia, Central \& Eastern Europe, ASEAN and West Asia. The regression results are shown in Table 7.

Table 7 robust regression analysis of bilateral trade model 


\begin{tabular}{|c|c|c|c|c|c|}
\hline & $\begin{array}{l}\text { Central } \\
\text { Asia }\end{array}$ & South Asia & $\begin{array}{l}\text { Central \& Eastern } \\
\text { Europe }\end{array}$ & ASEAN & West Asia \\
\hline \multirow[t]{2}{*}{$L N G D P_{i}$} & 0.063991 & 0.214647 & $0.682336^{\star}$ & $0.845174^{\star}$ & $0.248225^{\star}$ \\
\hline & $(0.284467)$ & $(1.407646)$ & (14.77180) & (10.11135) & (3.776103) \\
\hline \multirow[t]{2}{*}{$L N G D P_{j}$} & $0.941409 *$ & $0.903117^{\star}$ & $0.915398^{*}$ & $0.660635^{\star}$ & $1.056731^{*}$ \\
\hline & (3.549798) & (14.31794) & $(25.45924)$ & $(8.432675)$ & (9.861981) \\
\hline \multirow[t]{2}{*}{ LNDIS } & -2.633330 & $-1.858127^{\star}$ & 0.225623 & $-1.357584^{\star \star \star}$ & -1.648303 \\
\hline & $(-0.658406)$ & $(-3.193092)$ & $(0.847972)$ & $(-1.744177)$ & $(-0.799799)$ \\
\hline \multirow[t]{2}{*}{ LNWEF } & 0.167756 & $1.627423^{\star}$ & $0.759197^{\star}$ & $0.903672^{\star \star}$ & $1.258311 *$ \\
\hline & $(0.331002)$ & (3.718248) & (5.782335) & $(2.478173)$ & (3.928803) \\
\hline \multirow[t]{2}{*}{ C } & 19.62017 & $8.439539 * \star \star$ & $-13.65348^{\star}$ & -1.568486 & 6.519313 \\
\hline & $(0.591457)$ & (1.724144) & $(-5.714424)$ & $(-0.248570)$ & $(0.358005)$ \\
\hline ADjustedR ${ }^{2}$ & 0.298518 & 0.860002 & 0.870770 & 0.754835 & 0.682457 \\
\hline Fstatistics & 6.744970 & 100.8227 & 258.7343 & 84.89976 & 59.56509 \\
\hline PValue & 0.000202 & 0.000000 & 0.000000 & 0.000000 & 0.000000 \\
\hline
\end{tabular}

Note: the data in brackets are regression coefficients, and the data in brackets are t statistics. "*", "**", "* *", "* *" were significant at $1 \%, 5 \%$ and $10 \%$ levels, respectively.

It can be seen from table 7 that except for Central Asia, the goodness of fit of bilateral trade models in other regions is relatively high, especially in South Asia and central and Eastern Europe, with the revised $R 2$ values of 0.860 and 0.871 respectively. The significance level of $P$ value in each region is more than 1\%. In Central Asia and West Asia, the gap between China's GDP and the GDP of trading countries on the bilateral trade volume is very obvious. The regression coefficients of LNGDPi and LNGDPj in Central Asia are 0.064 and 0.941 respectively, while those in West Asia are 0.248 and 1.058 respectively. In the ASEAN region, China's GDP has a greater impact on the bilateral trade volume than the GDP of trading countries, with the regression coefficients of 0.845 and 0.661 respectively. Except for central and Eastern Europe, LNDIS has a negative impact on bilateral trade volume. The degree of hindrance of geographical distance to bilateral trade volume from small to large is as follows: ASEAN $(-1.358)<$ West Asia $(-1.648)<$ South Asia $(-1.858)<$ Central Asia $(-2.633)$. The quality of port infrastructure in each region has a positive effect on bilateral trade volume. For every $1 \%$ increase in LNWEF in South Asia, bilateral trade volume will increase by about $1.63 \%$, which is significant at the level of $1 \%$. For every $1 \%$ increase in LNWEF in Western Asia, LNTRA increases by $1.26 \%$, which is also significant at the level of $1 \%$. The regression coefficients of LNWEF in CEE and ASEAN are 0.759 and 0.904 , which are significant at the level of $1 \%$ and $5 \%$ respectively. 


\subsection{Regression results of bilateral trade model}

Both the overall regression results and the regional regression tests show that the bilateral trade model constructed in the article has a good fit, which can better reflect the economic scale, geographical distance, port infrastructure quality and three control variables (common border, FTA and APEC) impact on bilateral trade between China and countries along the "Belt and Road". The specific analysis is as follows:

First, the scale of the economy has a positive effect on the growth of bilateral trade between China and countries along the "Belt and Road". The article uses China's GDP and the GDP of trading countries to comprehensively measure the impact of economic scale on bilateral trade, and more accurately shows that the strength of a country's economic strength will have a significant stimulating effect on the country's trade. From the regression results, it can be found that the economic scale of the trading countries in Central Asia, South Asia, Central and Eastern Europe, and West Asia has a more obvious positive effect on the growth of bilateral trade. The main reason may be that these countries are importing countries for China's exports. The huge demand capacity shows that the "Belt and Road" initiative meets the needs of the economic development of all countries and has a broad space for development.

Second, geographic distance has a negative effect on the growth of bilateral trade volume between China and the countries along the "Belt and Road". Generally speaking, the farther the distance between the two countries is, the higher the various trade costs of trade exchanges between the two sides will be, and the less conducive to the development of bilateral trade. However, from the regression results of the article, the negative impact of geographic distance on trade is not absolute. The signs of geographic distance in models (1) (3) are all opposite to expectations. The article believes that there are two main reasons: one is that with the advent of the Internet information age, people can freely conduct large-scale crossborder e-commerce transactions online, and the hindrance of geographical distance to bilateral trade is getting smaller and smaller or even negligible. Second, with the implementation of the "Belt and Road" project, China and its partner countries have become increasingly close in terms of facility connectivity. Not only have they signed a series of transport agreements involving sea, land, and air transport, but also successfully built railways and highways extending in all directions; making transportation more convenient and efficient, thereby reducing the adverse impact of geographic distance on bilateral trade.

Third, the quality of port infrastructure has a positive effect on the growth of bilateral trade between China and countries along the "Belt and Road". Shipping has always been an important means of transportation of goods in the development of foreign trade by countries all over the world. With the rapid development of land transportation, air transportation and even multimodal transportation, the role of sea transportation in connecting countries' trade is becoming more and more important. The quality of port infrastructure is an important indicator that determines the efficiency of shipping. The regression results show that in Southeast Asia and West Asia, where shipping is developed, high-standard port infrastructure quality can bring good development benefits to the opening of regional trade. 
Fourth, having common borders, signing FTAs and joining APEC have a positive effect on the growth of bilateral trade between China and countries along the "Belt and Road". First of all, the countries with a common border have more in common in the cultural backgrounds, language, customs, etc., and it is easier to reach consensus in business exchanges, which creates a good cultural environment for the smooth development of bilateral trade. Secondly, signing an FTA can bring more preferential tariff policies to trading countries, eliminate the hindrance of tariff and non-tariff barriers as much as possible, and create a stable trading environment for the growth of bilateral trade. Finally, joining APEC shows that member states share common economic development objectives and social development aspirations, and create a harmonious institutional environment for the promotion of bilateral trade.

\section{Proposals To Promote The Strengthening Of Bilateral Trade Between China And Countries Along The "belt And Road"}

Through regression analysis, it can be seen that the article summarizes the conclusions from two dimensions: First, from the overall regression model, the economic scales of China and trading countries are conducive to the expansion of bilateral trade, and the positive effect of trading countries' GDP is stronger. Geographical distance will hinder the growth of bilateral trade volume. The higher the quality of

port infrastructure, the better the bilateral economic and trade cooperation. Signing FTA and joining APEC are also beneficial to in-depth cooperation between the two parties. Second, from the group regression model, the regression coefficient sign of each variable is still consistent with the hypothesis. Except for the Central Asia region, the goodness of fit of the models in the other regions is also relatively high and passed the robustness test. Based on the above-mentioned conclusions, the article puts forward four targeted suggestions to promote the strengthening of bilateral trade between China and the countries along the "Belt and Road".

\subsection{Deepen economic and trade cooperation and promote economic development}

Since the launch of the "Belt and Road" initiative, China has always followed the principle of extensive consultation, joint contribution and shared benefits, guided by the spirit of the Silk Road, and has carried out cooperation in various fields with countries along the "Belt and Road". Economic and trade cooperation between China and relevant countries continues to improve. The empirical analysis of the article shows that both the expansion of China's economic scale and the economic growth of trading countries will significantly promote the increase of bilateral trade. Therefore, China should continue to increase bilateral trade with countries along the "Belt and Road", especially Kazakhstan, Turkmenistan and Uzbekistan in Central Asia. China and these countries have broad prospects for trade cooperation and huge opportunities for trade development. In addition, Saudi Arabia and the UAE in West Asia have abundant natural resources and have huge development potential with China in energy trade. On the basis of fully understanding the trade structure of partner countries, China can promote innovation in trade methods by establishing bilateral e-commerce cooperation mechanisms and launching new crossborder e-commerce models. While increasing the total trade volume, it should also focus on optimizing 
the trade structure, to promote the export of high-tech products and continuously promote the improvement of trade benefits.

\subsection{Speed up the signing of FTA and promote the construction of free trade zones}

The construction of a free trade zone is an important economic development strategy proposed by China. At present, the resolution of Sino-US trade frictions is still in a difficult negotiation stage. It is even more urgent to promote the implementation of the free trade zone strategy to eliminate trade barriers with signatories. Promoting trade liberalization between countries has become an urgent task at present. The signing of free trade agreements between China and various regions is in full swing, and a series of good results have been achieved. At present, the China-Sri Lanka Free Trade Area negotiations have attracted much attention. As the "Pearl of the Indian Ocean", Sri Lanka occupies a very important geographical location advantage on the Maritime Silk Road. The signing of a free trade agreement meets the needs of economic development between the two countries, but the current trade deficit between Sri Lanka and China is very serious. Besides, Sri Lanka itself is in the quagmire of foreign debt, which hinders the two parties from accelerating the pace of signing FTA. In view of the significant stimulus effect of signing FTA on bilateral trade volume, China should strive to seek the common will of all countries to cooperate, more proactively promote negotiations with countries along the route, and accelerate the establishment of higher-quality and higher-level free trade areas, and trade partners.

\subsection{Strengthen modern logistics cooperation and reduce the hindrance of geographical distance}

The empirical analysis of the article shows that geographic distance will have a negative impact on bilateral trade. In order to promote the implementation of facility connectivity in the "five links", reduce the barriers of geographic distance, and strengthen the modern logistics cooperation between China and the countries along the "Belt and Road" is necessary. With the rapid development of emerging information technologies such as the sharing economy and artificial intelligence, a number of new platform-based logistics companies have sprung up, and the logistics development mode is in the stage of transformation and upgrading. The continuous advancement of the "Belt and Road" initiative puts forward higher requirements for logistics cooperation between China and the regions along the route. However, the current level of logistics cooperation between China and its trading partners is still at a low level, especially in Central and Eastern European countries such as Montenegro, Lithuania, Bosnia and Herzegovina, and Slovenia. Various problems are emerging one after another such as poor quality of infrastructure, Logistics information level is low, international logistics channels are not well connected, etc. Opportunities and challenges coexist in the logistics cooperation with countries along the "Belt and Road". In terms of specific measures, attention should be paid to integrating the relevant resources of China's logistics supporting facilities, speeding up the construction of supporting facilities, and striving to form a modern logistics network system with all-round sea, land, air and rail interoperability.

5.4 Improve the construction of port infrastructure and optimize the trading environment 
The quality of port infrastructure is not only a key factor in determining the level of logistics performance, but also an important indicator to measure the level of trade facilitation. It is also of great significance for promoting the interconnection of infrastructure and trade between China and countries along the route in the "Belt and Road" initiative. In recent years, China has paid more and more attention to participating in port construction and operation projects in countries along the "Belt and Road", especially in the vicinity of the Indian Ocean. Few port-building projects are there; For example, the establishment of Huangjing Port in Malaysia has not only improved Malaysia's port construction capabilities, but also served the busy Malacca Strait routes more efficiently and conveniently, becoming a key link in boosting the development of the Maritime Silk Road. At present, the level of China's port construction is becoming more and more competitive in the international arena. However, it cannot be ignored that the construction of China's port infrastructure still faces problems such as low quality, long customs clearance cycles and low customs clearance convenience. To this end, China should continue to improve the construction of port infrastructure, shorten the customs clearance cycle, and improve port convenience. At the same time, countries should continue to explore the construction plan of a free trade port, use the port as a bridge to promote the construction of a large maritime logistics channel, pay more attention to the security, intelligence of the port, and build a comprehensive, professional and three-dimensional infrastructure. At the age of Tech era, thus creating more convenient customs clearance conditions for China's economic and trade cooperation with countries along the route is necessary.

\section{References}

[1] Fardella EnricoखProdiGiorgio. The Belt and Road Initiative Impact on Europe: An Italian Perspective[J]. China \& World Economy $₫ 2017 \llbracket 25(5):$ 125-138.

[2] IrshadMuhammad Saqib囚Hamza Arshad. An empirical analysis of Pakistan's bilateral trade and trade potential with China: A gravity model approach[J]. Cogent Economics \& Finance冈2018ه6(1).

[3] Shakur冈 Shamim. Impact of trade cost on China-EU agri-food trade[J]. Journal of Chinese Economic and Business Studies $₫ 201816(3)$ : 259-274.

[4] Siobhan Murray $\llbracket$ Nadia Rocha $₫$ Michele Ruta. How much will the Belt and Road Initiative reduce trade costs?[J]. International Economics $₫ 2019 \rrbracket 159$.

[5] RamasamyBalaهYeungMatthew $\mathrm{C} \mathrm{H}$. China's one belt one road initiative: The impact of trade facilitation versus physical infrastructure on exports[J]. The World Economy $₫ 2019 \llbracket 42(6)$ : 1673-1694.

[6] Papalia R. B. \& Bertarelli S. . Trade costs in bilateral trade flows: Heterogeneity and zeroes in structural gravity models[J]. The World Economy $₫ 2015 \varangle 38(11): 1744$.

[7] Kazar G『Kazar A『Sert T S. Bilateral Trade in European Sports Industry: Linder versus Hecksher-OhlinSamuelson[J]. International Journal of Economics and Financial Issues $₫ 2018 \otimes 8(1)$ : 48. 
[8] Hussain Z.『Hanif N.『Wasim A. S. \& Nadeem M.. Empirical analysis of multiple infrastructural covariates: An application of gravity model on asian economies[J]. Asian Economic and Financial Review $₫ 2019 \llbracket 9(3): 299-317$.

[9] François de Soyres $₫$ Alen Mulabdic $₫$ Michele Ruta. Common transport infrastructure: A quantitative model and estimates from the Belt and Road Initiative[J]. Journal of Development Economics $\$ 2019 \bigotimes 143$.

[10] Tan Xiujie, Zhou Maorong. The 21st Century "Maritime Silk Road" Trade Potential and Its Influencing Factors-An Empirical Study Based on Stochastic Frontier Gravity Model[J]. International Trade Issues, 2015(2):3-12.

[11] Li Xiaohui. Research on the Influencing Factors and Potentials of Bilateral Trade between China and Countries along the "Belt and Road" [D]. Liaoning University, 2016.

[12] Liu Hongduo, Li Wenyu, Chen He. How does cultural fusion affect China's bilateral trade with countries along the "Belt and Road": An empirical test based on micro-trade data from 1995 to 2013 [J]. International Trade Issues, No.398 (02): 5-15.

[13] Zhang Huiqing. Research on the trade potential between China and the areas along the "Belt and Road" [J]. International Trade Issues (07): 87-97.

[14] Yang Qing, Zhang Cuizhen. Influencing factors of trade flow between China and the countries along the "Belt and Road"[J]. International Economic Cooperation, 2018(5).

[15] Fang Ying, Ma Rui. Cultural trade potential and influencing factors between China and the countries along the "Belt and Road": an empirical study based on the stochastic frontier gravity model [J]. World Economic Research, 2018(01): 112-121+136.

[16] Deng Zixuan. Research on Influencing Factors of Cultural Trade between China and Countries Along the Belt and Road under the Background of "One Belt One Road" [D]. Hunan Normal University, 2019.

[17] Zuo Ximei. Analysis of the trade influence factors and trade potential between China and neighboring countries under the strategic background of the Silk Road Economic Belt-Based on the Research of the Extended Gravity Model [J]. Financial Development Review, 2016(07): 130-145.

[18] Zhang Jianguang, Zhang Peng. Research on the trade efficiency and influencing factors between China and the "Belt and Road" countries [J]. International Economics and Trade Research (08): 5-24.

[19] Cao Wei, Lin Shouwu. Changes in the RMB exchange rate, the effects of neighboring countries' exchange rates and bilateral trade: An empirical study based on the SVAR model between China and the five Southeast Asian countries [J]. International Trade Issues (11): 152-163.

[20] Hou Wenyu. Analysis of the trade pattern and influencing factors between China and the countries along the "Belt and Road" [D]. China University of Geosciences (Beijing), 2018. 
[21] Zhang Yanyan, Yu Jinping. Transportation infrastructure, proximity effects and bilateral trade: An empirical study based on trade data between China and the "Belt and Road" countries[J]. Contemporary Finance, 2018(03): 98-109.

[22] Wan Yongbin. An Empirical Study on the Influencing Factors of Bilateral Trade between China and Countries Along the "One Belt and One Road"[J]. Exploration of Economic Issues, 2019(11):134-141.

[23] Li Xiaozhong, Du Tianhao, Wang Shuyu. Research on the Influencing Factors and Potentials of Trade between China and Countries along the "One Belt and One Road" [J]. International Economic Cooperation, 2019(03):17-29.

\section{Figures}

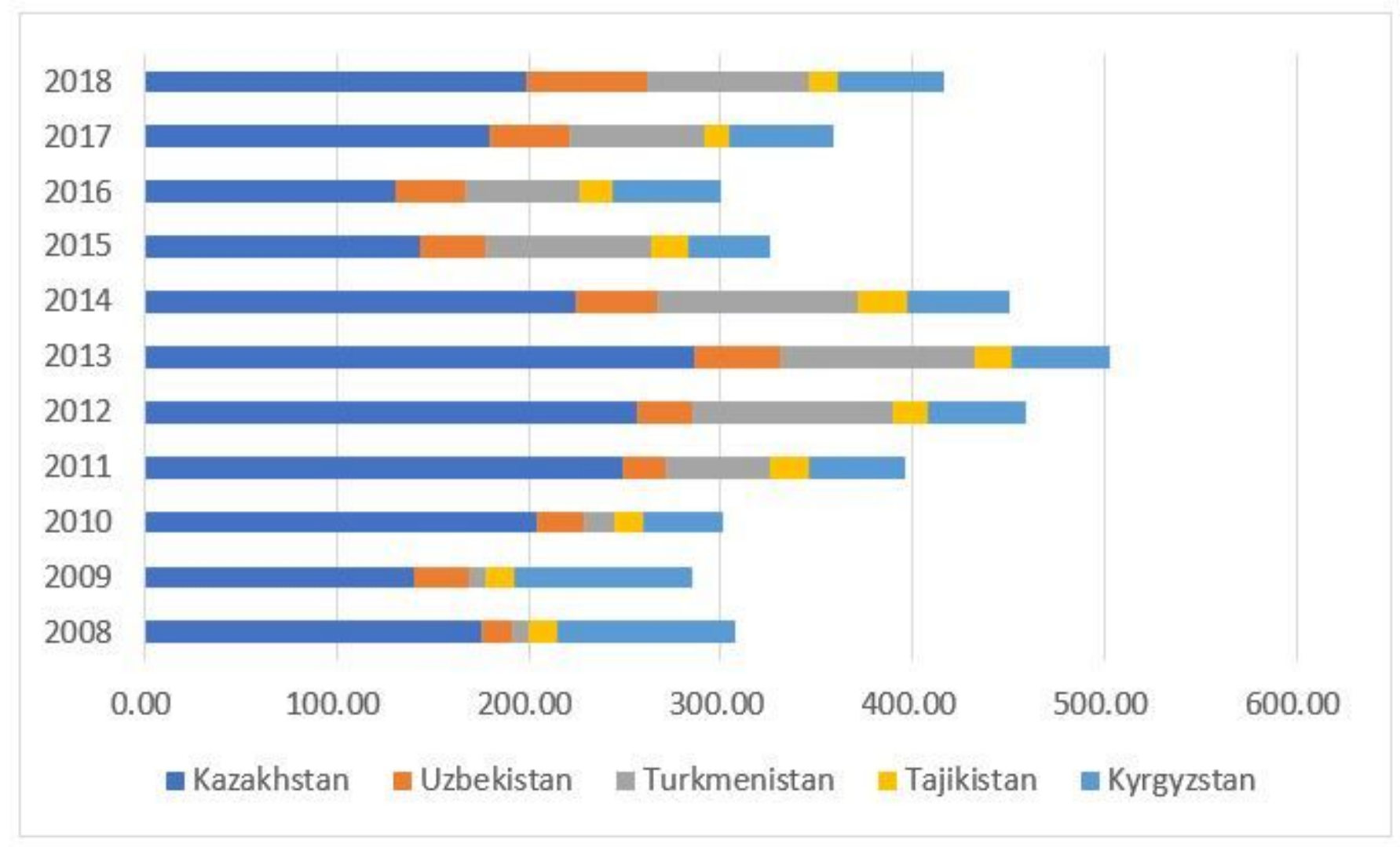

\section{Figure 1}

bilateral trade volume between China and five Central Asian countries from 2008 to 2018 unit: US \$100 million; Source: World Bank Database 


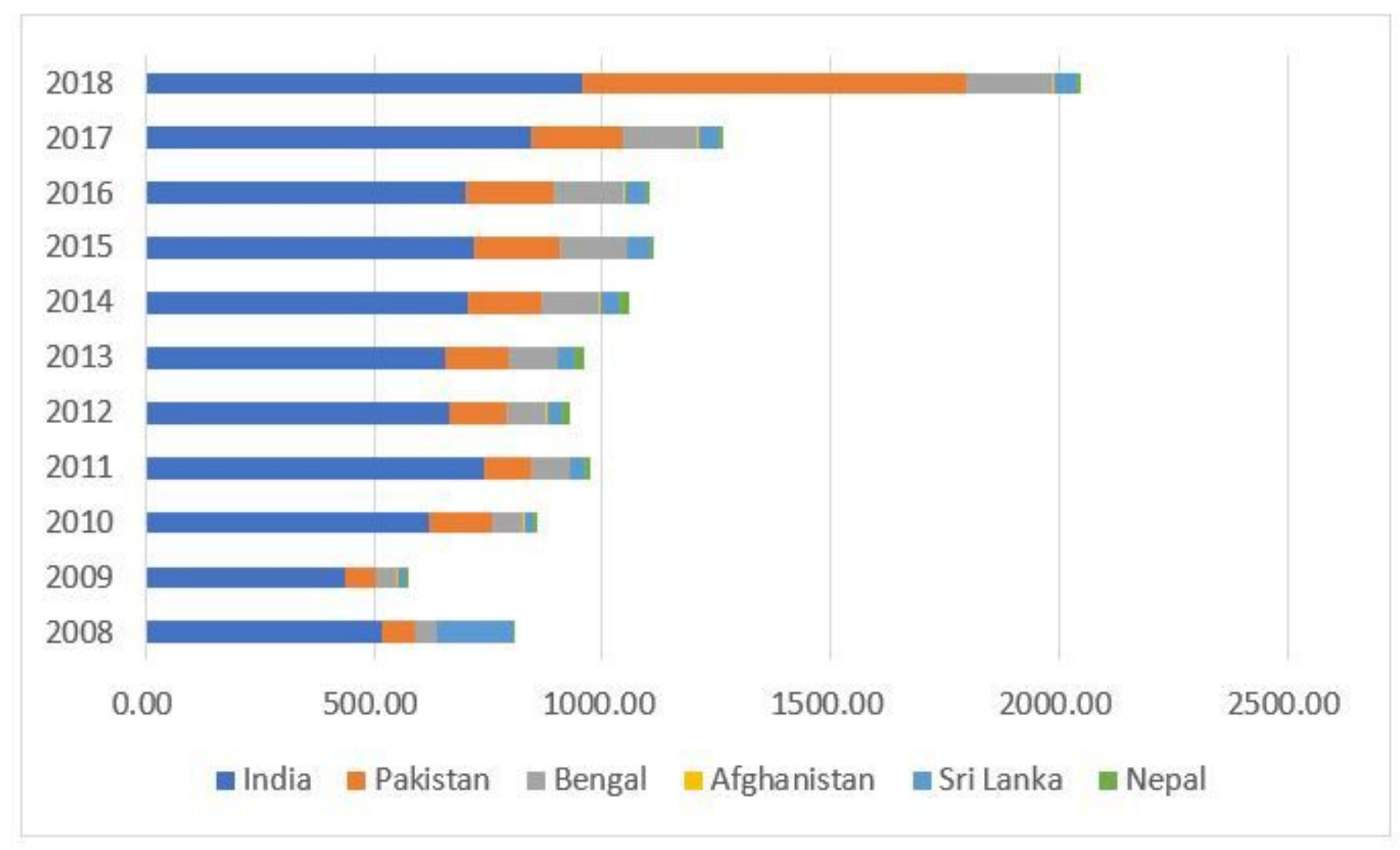

\section{Figure 2}

bilateral trade volume between China and six South Asian countries from 2008 to 2018 unit: US \$100 million; Source: World Bank Database

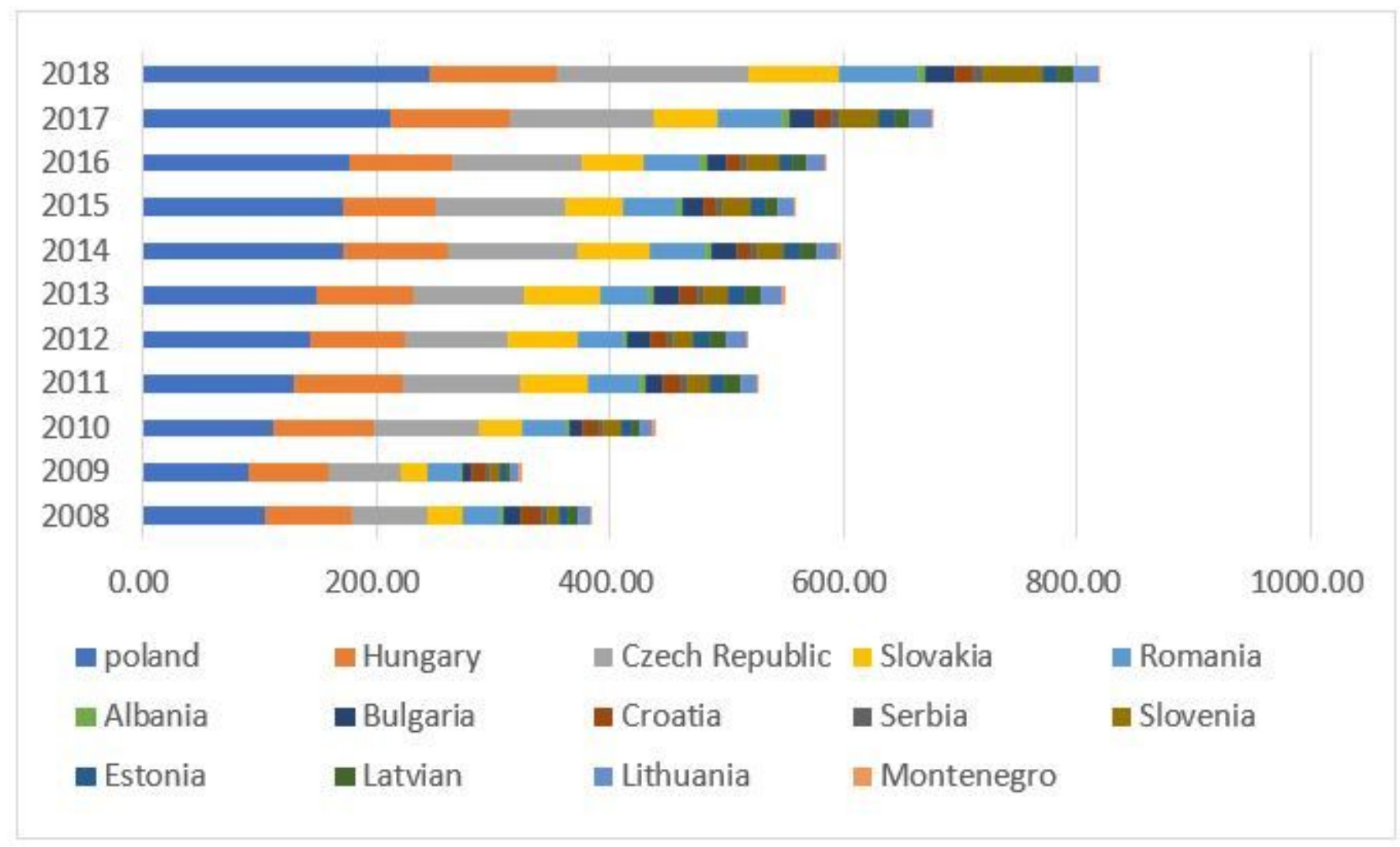




\section{Figure 3}

bilateral trade volume between China and 14 central and Eastern European countries from 2008 to 2018 unit: US \$100 millionखSource: World Bank Database

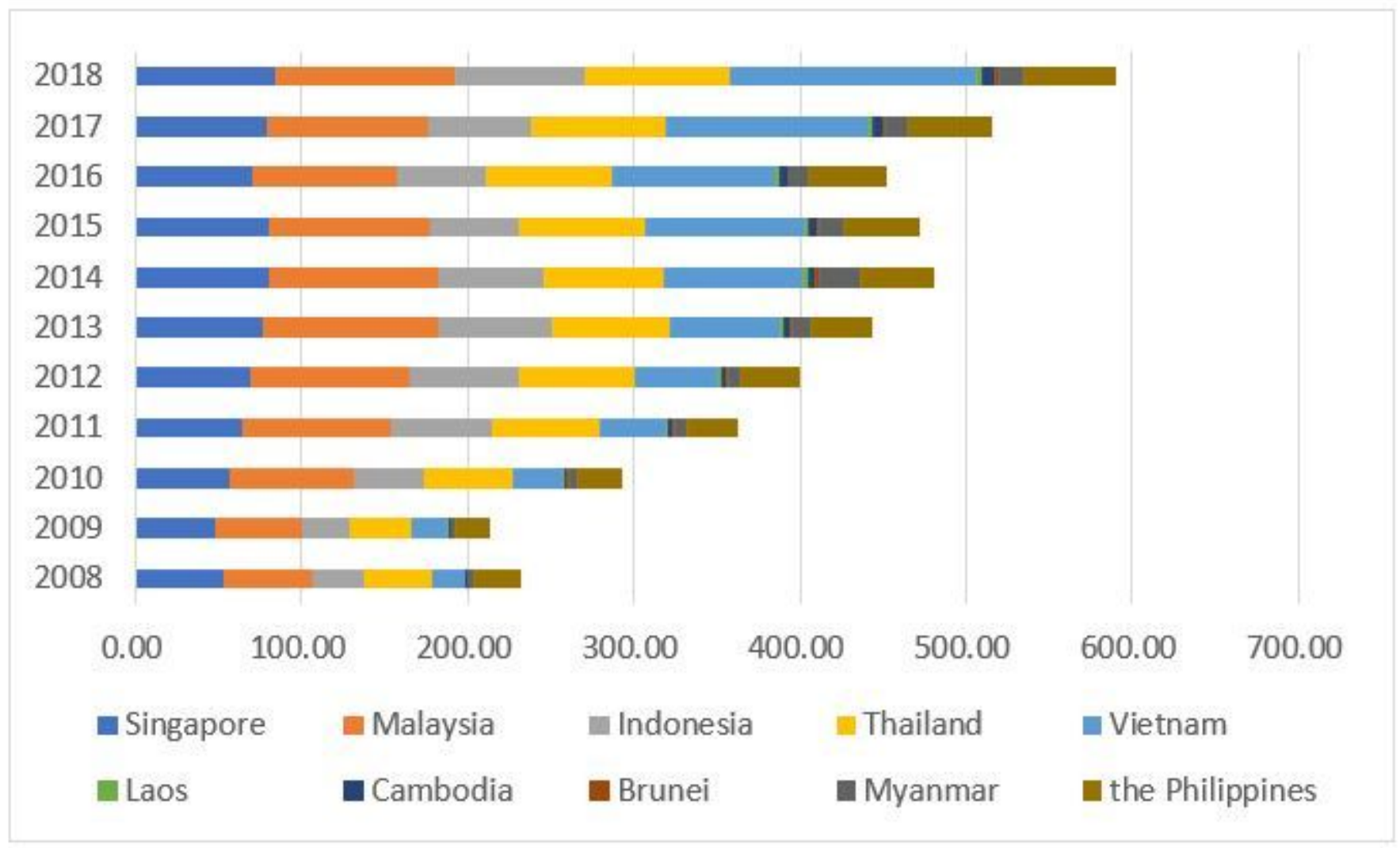

\section{Figure 4}

bilateral trade volume between China and ten ASEAN countries from 2008 to 2018 unit: US $\$ 100$ million》 Source: World Bank Database 


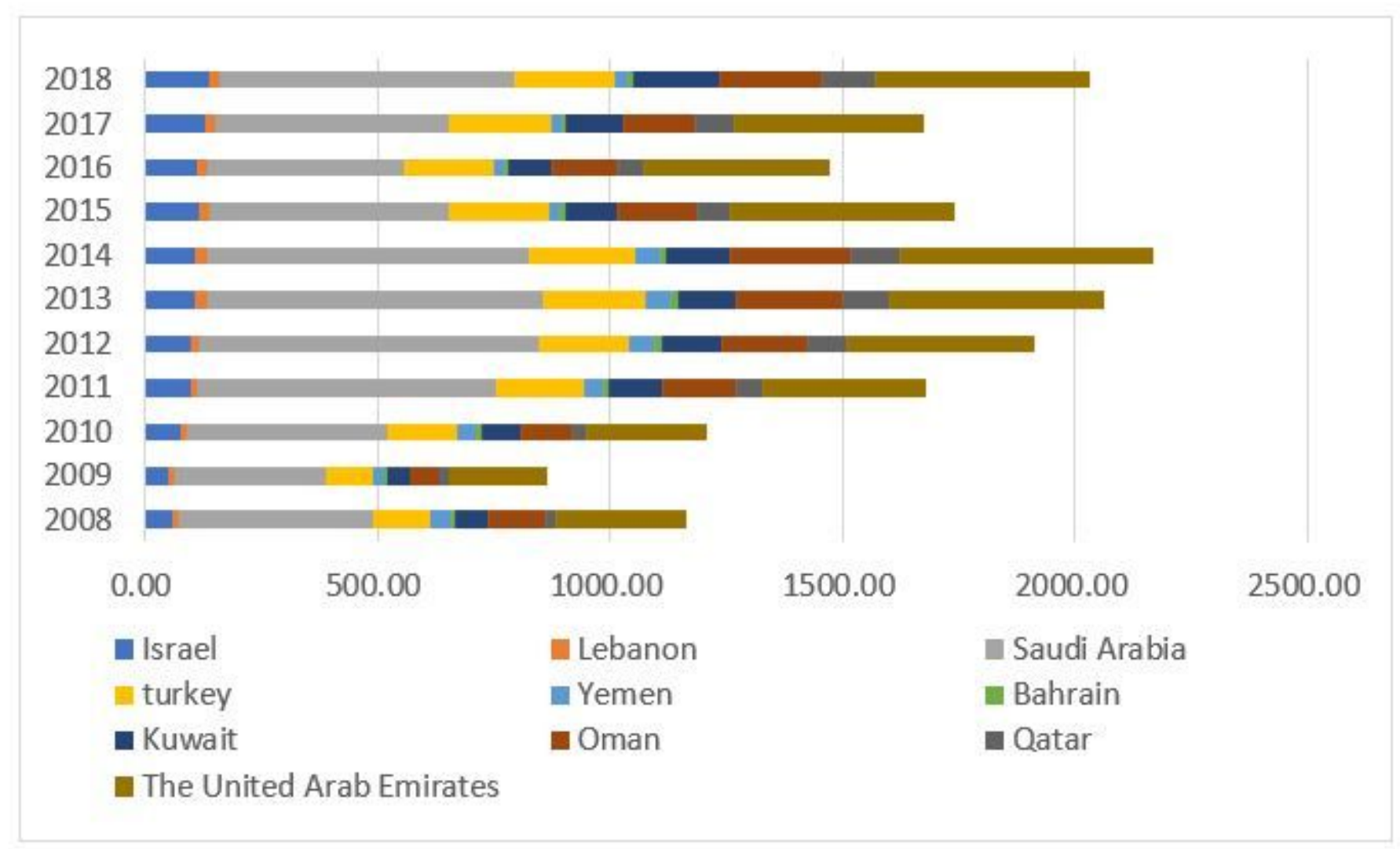

\section{Figure 5}

bilateral trade volume between China and ten West Asian countries from 2008 to 2018 unit: US $\$ 100$ million囚Source: World Bank Database 